Zbornik Instituta za kriminološka

i sociološka istraživanja

2021 / Vol. XL / 1 / 69-84

Originalni naučni rad

Primljeno: 24. marta 2021. godine

Prihvaćeno: 11. maja 2021. godine

DOI: $10.47152 /$ ziksi2021014

UDK: 159.923 .072

159.922.8.072

\title{
MRAČNA TETRADA I NEPOVOLJNI SREDINSKI USLOVI KAO FACILITATORI KONZUMACIJE PSIHOAKTIVNIH SUPSTANCI*
}

\author{
Andrijana Damjanović ${ }^{*}$ \\ Janko Međedović*
}

\begin{abstract}
Mračna Tetrada je psihološki koncept koji opisuje amoralnu i antisocijalnu stranu ljudske ličnosti pomoću četiri crte Makijavelizma, narcizma, psihopatije i sadizma. Cilj ovog istraživanja bio je ispitati vezu između dimenzija Mračne Tetrade ličnosti, nepovoljnog sredinskog okuženja tokom razvoja $i$ konzumacije psihoaktivnih supstanci (PAS). Korišćenjem "online" ankete u prikupljen je uzorak od 239 ispitanika (55.65\% ženskih ispitanika). Rezultati su pokazali da je psihopatija najvažniji prediktor upotrebe PAS-a jer nezavisno pozitivno predviđa sve ispitivane klase psihoaktivnih supstanci. Narcizam je pokazao nezavistan pozitivan doprinos pri predikciji konzumacije cigareta $i$ kanabisa ali $i$ ukupne mere upotrebe supstanci. Makijavelizam i sadizam su imali pozitivne korelacije sa nekim od ispitivanih kriterijuma ali ne $i$ nezavistan doprinos u regresionim modelima što znači da se detektovane bivarijantne asocijacije mogu svesti na relacije između drugih mračnih crta i konzumacije PAS-a, najverovatnije psihopatije. Nisu pronađene veze između nepovoljne sredine $i$ kreterijumskih varijabli kao ni interakcije mračnih crta i sredine pri predikciji. $U$ radu se diskutuju implikacije nalaza uzimajući u obzir i ograničenja samog istraživanja.
\end{abstract}

\footnotetext{
* Ovaj rad nastao je kao rezultat istraživačkog angažovanja prema Planu i programu rada Instituta za kriminološka i sociološka istraživanja za 2021. godinu.

* Fakultet za medije i komunikacije, Beograd; master psiholoških nauka. E-mail: damjanovicanja@yahoo.com

* Institut za kriminološka i sociološka istraživanja, Beograd; viši naučni saradnik. E-mail: janko.medjedovic@fmk.edu.rs
} 


\author{
Zbormik IKSI, 1/2021 - A. Damjanović, J. Međedović \\ „Mračna Tetrada i nepovoljni sredinski uslovi kao facilitatori konzumacije \\ psihoaktivnih supstanci”, (str. 69-84)
}

\begin{abstract}
KLJUČNE REČI: mračna tetrada / psihoaktivne supstance / nepovoljna sredina
\end{abstract}

\title{
UVOD
}

\section{Mračna Tetrada}

Mračna Tetrada opisuje ličnosne dispozicije ka antisocijalnom i amoralnom ponašanju i te stoga predstavlja set crta ličnosti koji je povezan sa socijalno nepoželjnim ishodima (Paulhus, 2014). Čine je četiri crte: psihopatija, narcizam, Makijavelizam i sadizam. Makijavelizam, kao crta ličnosti, karakteriše sklonost ka obmanjivanju, tj. manipulaciji, cinizam i pragmatična etika (Alsheikh Ali, 2020). Pomenuta crta uključuje i sklonost ka neodgovornom ponašanju i donošenju odluka zasnovanom na manipulaciji (Weng, Ran, \& Chui, 2016), kao i amoralnost (Pajević, Vukosavljević-Gvozden, Stevanović \& Neumann, 2018) i isključiva koncentrisanost na sopstvene interese. Kao crta, možda je najbolje objašnjiv kao dispoziciona tendencija za manipulaciju i eksploataciju drugih (Christie \& Geis, 1970).

Narcistične osobe imaju izuzetno visoko mišljenje o sebi, zahtevaju divljenje, poštovanje i visoki status u društvu, jer je njihovo iskreno verovanje da to upravo i zaslužuju. Ovaj profil osoba poseduje izuzetno visoku želju za dominacijom, a njihova sposobnost da osećaju krivicu je prilično niska (Jonason, Li, Webster, \& Schmitt, 2009). Psihopatiju čine nekoliko karakteristika ličnosti (Williams, Paulhus, \& Hare, 2007). Jedna od najvažnijih je emotivna površnost, emotivna hladnoća, koja se opisuje manjkom emotivne empatije za druge, manjkom osećanja straha i krivice. Prisutno je manipulativno ponašanje, prevrtljivost, koristoljubivost, tendencija da se zloupotrebe drugi. Većina autora dodaje i denzihibiciju, teškoću da se kontroliše ponašanje, impulsivnost, nepromišljenost, i najzad neki autori dodaju kao četvrtu crtu, antisocijalno i kriminalno ponašanje (Hare, 2003). Osobe s izraženom psihopatijom imaju smanjenu sposobnost inhibicije antisocijalnih impulsa (Foster i Trimm, 2008). Mogu biti i samodestruktivni i destruktivni, skloni nasilju i konzumiranju alkohola (Neumann \& Hare, 2008).

Za sadizam je karakteristično agresivno ponašanje, kao i osećaj prijatnosti i uzbuđenosti koji se javlja prilikom nanošenja fizičkog ili emotivnog bola drugim osobama (Buckels, Jones \& Paulhus, 2013). Sadizam se kvalitativno razlikuje od ostalih crta Mračne Tetrade zato što postoji pozitivna emocija - prisustvo zadovoljstva, koje osoba oseća kada povređuje drugog ili posmatra drugog kako pati (Međedović, 2017) i baš to uživanje u okrutnosti definiše sadizam, a ne želja za moći (Foulkes, 2019). Osobe sa sadističkim, za razliku od ostalih crta, demonstriraju okrutno ponašanje pokrenuto unutrašnjom motivacijom da nanesu patnju nevinoj, slabijoj osobi (Buckels, Jones, \& Paulhus, 2013). Zbog toga je sadizam povezan ne samo sa kriminalnim dispozicijama (Međedović \& Kovačević, 2020) već i sa 


\section{Zbormik IKSI, 1/2021 - A. Damjanović, J. Međedović \\ „Mračna Tetrada i nepovoljni sredinski uslovi kao facilitatori konzumacije \\ psihoaktivnih supstanci", (str. 69-84)}

uverenjima koja predstavljaju osnovu ideološki motivisanog nasilja kao što su stavovi karakteristični za militantne ekstremiste (Međedović \& Knežević, 2019).

\section{Psihoaktivne supstance}

Psihoaktivne supstance u najširem smislu predstavljaju hemijske supstance koje prvenstveno deluju na nervni sistem, menjajući funkcionisanje mozga, a koje rezultira privremenim ili trajnim promenama u percepciji, raspoloženju, svesti i ponašanju (Mitrović, 2005). Konzumacija psihoaktivnih supstanci predstavlja globalni problem koji pogađa kako fizičko, tako i mentalno zdravlje. Značajni problemi se mogu javiti u okviru cele društvene zajednice, upravo zbog oštećenja fizičkog i mentalnog zdravlja korisnika i socio-ekonomskih problema za njihovo neposredno okruženje. Usled povišenih psihopatoloških doživljaja, impulsivnosti i agresivnosti, može doći do zlostavljanja članova porodice, neispunjavanja društevnih uloga, gubitka duševnog mira svih osoba koje se nalaze u njihovoj blizini (Marković, 2016). Važno je naglasiti da problemi vezani sa konzumacijom psihoaktivnih supstanci ne postoje samo kod osoba zavisnih od psihoaktivnih supstanci, već i kod kod onih koji umereno konzumiraju ili ponekad prekomerno konzumiraju. S tim u vezi, neophodno je dodatno istražiti faktore koji dovode do konzumacije psihoaktivnih supstanci, kako bi se stvorili bolji sistemi zaštite i uticaja kako na pojedinca, tako i na društvo u celini.

\section{Mračna tetrada i konzumacija psihoaktivnih supstanci}

Psihološki faktori mogu imati veliku ulogu kada je reč o konzumiranju psihoaktivnih supstanci. Jedan od psiholoških faktora koji može uticati na konzumiranje psihoaktivnih supstanci su i crte ličnosti, uključujući i mračne karakteristike ličnosti. Konzumiranje lakših i težih narkotika se uveliko javlja kod osoba sa psihopatskim osobinama (Hicks, Vaidyanathan, \& Patrick, 2010). Makijevalizam je dokazan kao jedan od prediktora i faktora rizika za konzumiranje ilegalnih supstanici, posebno kokaina (Quednow, Hulka, Preller, Baumgartner, Eisenegger \& Vonmoos, 2017). Upotreba supstanci je povezana sa impulsivnošću, potragom za uzbuđenjem, grandioznošću, bezosećajnošću, nižim nivoom savesnosti i nižim nivoom saradljivosti, što su sve zajedničke karakterisitke mračnih crta (Kotov, Gamez, Schmidt \& Watson, 2010). Agresivnost je jedna od zajedničkih osobina svih crta ličnosti koje spadaju u Mračnu Tetradu, posebno kada je reč o sadizmu, a ona sama spada u faktore rizika koji mogu dovesti do konzumiranja psihoaktivnih supstanci (Anderson, 2006). Nepovoljno socijalno okruženje, niži socioekonomski status
i konzumacija psihoaktivnih supstanci

Oni koji konzumiraju psihoaktivne supstance često su u detinjstvu bili izloženi faktorima van njihove kontrole, kao što su siromaštvo, nasilje, nedostatak roditeljske 


\section{Zbormik IKSI, 1/2021 - A. Damjanović, J. Međedović \\ „Mračna Tetrada i nepovoljni sredinski uslovi kao facilitatori konzumacije psihoaktivnih supstanci", (str. 69-84)}

brige i ljubavi. Pored crta ličnosti, upravo ovi različiti aspekti okruženja mogu facilitirati konzumiranje psihoaktivnih supstanci (Kovačević, 2002). Deca i adolescenti, koji su izloženi roditeljskom maltretiranju, mogu imati osećanja bespomoćnosti, rastrojstva, nepostojanosti i mogu imati problem sa samoregulacijom afektivnih stanja. Postojeće studije su pokazale vezu između različitih formi zlostavljanja tokom detinjstva i korišcenja ilegalnih droga u adolescenciji (Dube, Felitti, Dong, Chapman, Giles, \& Anda, 2012). Još jedan od načina na koji negativna iskustva u detinjstvu mogu uticati na povećano antisocijalno i nasilno ponašanje, time $\mathrm{i}$ na konzumaciju PAS jesu same karakteristike traumatskog iskustva, nemogućnost da se asimiluje negativno iskustvo u psihičke strukture i reprezentacije (Dragioti, Damigos, Mavreas, \& Gouva, 2012). Neke teorije zastupaju stav da siromaštvo može indirektno da utiče na razvoj ishoda kao što je konzumacija psihoaktivnih supstanci, tako što povećava roditeljski stres, a time se smanjuje kvalitet roditeljstva (Conger, Wallace, Sun, Simons, McLoyd \& Brody, 2002).

\section{Cilj istraživanja i straživački problem}

Mračne crte ličnosti se do sada nisu izučavale zajedno kada je u pitanju objašnjenje konzumacije psihoaktivnih supstanci, a to se naročito odnosi i na uključivanje četvrte crte Mračne Tetrade, odnosno sadizma. Sumirajući navedenu literaturu, takođe, nijedno istraživanje se nije fokusiralo specifično na analizu crta ličnosti i sredinskih karakteristika pri predikciji konzumacije psihoaktivnih supstanci. Cilj ovog istraživanja je upravo zato bio ispitati vezu između dimenzija Mračne Tetrade ličnosti, sredinskih varijabli iz perioda odrastanja individue (dakle iz formativnih godina, odnosno one sredine koja bi trebalo da u najvećoj meri oblikuje bihejvioralne karakteristike) i konzumacije psihoaktivnih supstanci. Pored nezavisnog aditivnog doprinosa nepovoljnih sredinskih faktora i mračnih crta u predikciji konzumacije PAS-a, cilj istraživanja je bio i utvrditi da li postoji interakcija između ličnosnih i sredinskih faktora pri objašnjenju varijanse konzumacije PAS-a. Očekivali smo pozitivne asocijacije između crta Mračne Tetrade, nepovoljne sredine i konzumacije PAS-a; takođe, očekivali smo da osobe sa visoko izraženim mračnim crtama koje su u detinjstvu živele u nepovoljnom okruženju pokazuju posebno visoku verovatnoću konzumacije supstanci.

\section{METOD}

\section{Uzorak}

Uzorak na kome se vršilo istraživanje je prigodni uzorak. U našem istraživanju učestvovalo je ukupno 239 ispitanika, od čega 106 muškaraca (44.35\%) i 133 ženskihispitanika (55.65 \%). Uzorak su sačinjavale isključivo punoletne osobe (starije od 18 godina, starosti 20-34 godine; $\mathrm{M}=28.63$; $\mathrm{SD}=7.33$ ). U pogledu obrazovanja, $58 \%$ ispitanika je završilo fakultet, $29 \%$ je bilo u procesu studiranja 


\section{Zbormik IKSI, 1/2021 - A. Damjanović, J. Međedović \\ „Mračna Tetrada i nepovoljni sredinski uslovi kao facilitatori konzumacije psihoaktivnih supstanci", (str. 69-84)}

tokom prikupljanja podataka, 12\% je završilo srednju školu i 1 \% učesnika je završilo osnovnu školu. Zadavanje instrumenata je bilo računarski podržano i izvršeno tzv. metodom "snežne grudve", istraživač je anketu prosledio svojim poznanicima putem društvenih mreža, a oni su dalje prosledili svojim poznanicima.

\section{Instrumenti}

Mračna Tetrada ličnosti ispitana je upitnikom koji sadrži skalu Mračne Trijade (engl. Short Dark Triad: Jones \&Paulhus, 2012; za srpsku adaptaciju instrumenta videti Dinić, Petrović, \& Jonason, 2018) i skalu sadizma (Paulhus \& Jones, 2015; za srpsku adaptaciju instrumenta videti Međedović \& Petrović, 2015). Prva skala sastoji se ukupno od 27 ajtema, od kojih prvih devet mere Makijavelizam (M=26.13; $\mathrm{SD}=5.73$; $\alpha=.72)$ idućih devet narcizam $(\mathrm{M}=26.15 ; \mathrm{SD}=5.38 ; \alpha=.69)$, a poslednjih devet psihopatiju ( $\mathrm{M}=17.68 ; \mathrm{SD}=5.29 ; \alpha=.69)$. Druga skala koja meri sadizam $(\mathrm{M}=12.09$; $\mathrm{SD}=3.83 ; \alpha=.65)$ sastoji se ukupno od 7 ajtema i u pitanju je skala Direktnog Sadizma iz VAST upitnika (Paulhus \& Jones, 2015). Svi ajtemi se sastoje od izjavnih rečenica na koje ispitanici treba da izraze stepen svog slaganja koristeći petostepenu skalu Likertovog tipa.

Upitnik o nepovoljnom okruženju tokom detinjstva $(\mathrm{M}=2.31 ; \mathrm{SD}=.77 ; \alpha=.80)$ sastoji se od 9 ajtema (Međedović, 2020). Svi ajtemi sastoje se od izjavnih rečenica na koje ispitanici treba da izraze stepen svog slaganja koristeći petostepenu skalu Likertovog tipa. Ovih 9 ajtema mere dve varijable: jedna je porodična disfunkcionalnost koja meri nepovoljnost socijalnog okruženja (5 ajtema; primer ajtema: „Svađe i tuče su bile česte u kući u kojoj sam odrastao/la“), a druga meri nizak socioekonomski status u detinjstvu (4 ajtema; primer ajtema: „U mojoj porodici nikad nije bilo dovoljno novca“). Viši skorovi reprezentuju više izraženu porodičnu disfunkcionalnost i siromaštvo. S obzirom da su ove dve varijable pozitivno korelirale na uzorku ispitanika ove studije $(\mathrm{r}=.38 ; \mathrm{p}<.01)$ spojili smo ove dve mere u jedinstvenu varijablu Nepovoljno okruženje. I ovaj upitnik je već korišćen u istraživanjima i njegova validnost je potvrđena (Međedović, 2019).

Psihoaktivne supstance, čija se konzumacija nastojala ispitati ovim istraživanjem, odnosile su se na konzumaciju cigareta, konzumaciju alkoholnih pića i konzumaciju lakih i teških droga. Za merenje kozumecije supstanci koristili smo upitnik koji je konstruisan specifično za namere ovog istraživanja. Ajtemi se sastoje iz naziva supstanci kojih ukupno ima 14 (sve ispitivane supstance se mogu videti u Tabeli 1). Skala za odgovore meri frekventnost upotrebe svake od supstanci u poslednih godinu dana i ispitanici za svaku supstancu odgovaraju koliko često je konzumiraju. Ukupno ima 6 podeoka na skali, koji se odnose na frekvetnost upotrebe svake od supstanci: 1 - označava "nikada" , 2 - "veoma retko", 3 - "retko", 4 - "ponekad", 5 - " često" i 6 - "skoro svakodnevno ili svakodnevno". 
Zbornik IKSI, 1/2021 - A. Damjanović, J. Međedović

„Mračna Tetrada i nepovoljni sredinski uslovi kao facilitatori konzumacije
psihoaktivnih supstanci”, (str. 69-84)

\section{REZULTATI}

\section{Faktorska struktura konzumacije supstanci}

Pre nego što smo mogli da izvršimo analize koje testiraju naše hipoteze morali smo da redukujemo varijansu konzumacije pojedinačnih psihoaktivnih supstanci na manji broj latentnih komponenti kako bi smanjili broj izvršenih testova i verovatnoću greške tipa 2. U ovu svrhu je izvršena Analiza glavnih komponenti (sa Promax rotacijom) na pojedinačnim psihoaktivnim supstancama. Njeni rezultati sugerišu nam da se mogu izdvojiti četiri latentne komponente koje opisuju varijaciju opserviranih indikatora upotrebe supstanci. Kao što možemo videti u Tabeli 1, prva komponenta objašnjava oko $30 \%$ varijanse rezultata, druga oko $18 \%$, treća objašnjava oko $11 \%$, dok četvrta objašnjava oko $10 \%$ varijanse. Zajedno zahvataju oko $70 \%$ varijanse rezultata. Takođe možemo uočiti da određene supstance na različite načine zasićuju spomenute faktore. U prvom faktoru najveća pozitivna zasićenja imaju ekstazi (MDMA), kokain, amfetamin (SPID) i halucinogeni (LSD, gljive), u drugom su to alkoholna pića (pivo, vino, žestoka pića), u trećem su u pitanju drugi opijati/analgetici i sedativi, dok u četvrtom faktoru najjača pozitivna zasićenja imaju cigarete i kanabis (marihuana, hašiš). Radi lakšeg tumačenja rezultata, u nastavku rada prva komponenta će biti nazvana Konzumacija droga, druga Konzumacija alkoholnih pića, treća komponenta će biti nazvana Konzumacija opijata i sedativa, a četvrta Konzumacija cigareta i kanabisa.

Tabela 1: Koeficijenti sklopa ekstrahovanih komponenti

\begin{tabular}{|c|c|c|c|c|c|}
\hline \multirow[b]{3}{*}{ Cigarete } & \multirow[b]{2}{*}{$\mathrm{h}^{2}$} & \multicolumn{4}{|c|}{ Dobijene komponente } \\
\hline & & 1 & 2 & 3 & 4 \\
\hline & .75 & -.23 & -.01 & .13 & .89 \\
\hline Pivo & .73 & -.07 & .78 & -.20 & .28 \\
\hline Vino & .70 & .02 & .84 & .06 & -.23 \\
\hline Žestoka pića & .73 & .02 & .85 & .04 & -.05 \\
\hline $\begin{array}{l}\text { Druge } \\
\text { opijate/analgetike }\end{array}$ & .71 & .29 & .16 & .61 & .17 \\
\hline Sedative & .87 & -.09 & -.09 & .96 & .02 \\
\hline $\begin{array}{l}\text { Kanabis } \\
\text { (marihuana, } \\
\text { hašiš) }\end{array}$ & .65 & .43 & -.11 & -.12 & .61 \\
\hline Ekstazi (mdma) & .69 & .83 & .07 & -.04 & .00 \\
\hline Kokain & .58 & .78 & -.03 & .07 & -.14 \\
\hline Amfetamin (spid) & .49 & .65 & .08 & .05 & .05 \\
\hline $\begin{array}{l}\text { Halucinogeni } \\
\text { (LSD, gljive) }\end{array}$ & .61 & .82 & -.11 & -.07 & -.09 \\
\hline Varijansa & & $3 \cdot 30$ & 1.93 & 1.20 & 1.05 \\
\hline$\%$ varijanse & & 29.97 & 17.58 & 10.94 & 9.58 \\
\hline
\end{tabular}

Napomena: Zasićenja veća od .30 su boldovana u tabeli 


\section{Zbornik IKSI, 1/2O21 - A. Damjanović, J. Međedović \\ „Mračna Tetrada i nepovoljni sredinski uslovi kao facilitatori konzumacije psihoaktivnih supstanci”, (str. 69-84)}

\section{Korelati konzumacije supstanci}

Kao što možemo uočiti u Tabeli 2, postoje značajne korelacije komponenti konzumacije supstanci sa crtama ličnosti. Naime, Konzumacija droga je značajno pozitivno povezana sa psihopatijom i sadizmom. Konzumacija alkoholnih pića je značajno pozitivno povezana sa psihopatijom, narcizmom i Makijavelizmom. Ćetvrta komponenta, Konzumacija cigareta i kanabisa je značajno pozitivno povezana sa svim crtama Mračne Tetrade. Nisu zabeležene statistički značajne korelacije između crta mračne Tetrade i Konzumacije opijata i sedativa. S obzirom na to da su ustanovljene međusobne korelacije komponenti konzumacije supstanci, kreiran je skor koji meri ukupnu upotrebu psihoaktivnih supstanci. Navedena varijabla uključila je sve četiri inicijalne komponente konzumacije i dobijena je računanjem proseka verdnosti ostalih komponenti. Ta mera je statistički značajno pozitivno korelirala sa psihopatijom i sadizmom. Važno je primetiti da su izostale statistički značajne korelacije između svih navedenih varijabli i nepovoljne sredine. Ustanovljene su i značajne interkorelacije niskog do srednjeg reda veličine (izuzetak je samo visoka korelacija između sadizma i psihopatije) mračnih crta, što govori u prilog tome da su one distinktivne, ali međusobno povezane crte ličnosti, odnosno da imaju određene zajedničke karakterstike.

Tabela 2: Korelacije mračnih crta ličnosti, sredine i konzumacije supstanci

\begin{tabular}{|c|c|c|c|c|c|c|c|c|c|c|}
\hline & 1 & 2 & 3 & 4 & 5 & 6 & 7 & 8 & 9 & 10 \\
\hline 1. Makijavelizam & 1 & $.20^{* *}$ & $.43^{* *}$ & $.34^{* *}$ & -.09 & -.01 & $.14^{*}$ & -.00 & $.14^{*}$ & .11 \\
\hline 2. Narcizam & & 1 & $.31^{* * *}$ & $.18^{*}$ & -.10 & .10 & $.19^{* * *}$ & -.02 & $.26^{* *}$ & .21 \\
\hline 3. Psihopatija & & & 1 & $.57^{* *}$ & .01 & $.27^{* *}$ & $.22^{* *}$ & .05 & $.36^{* *}$ & $.35^{* * *}$ \\
\hline 4. Sadizam & & & & 1 & .08 & $.22^{* *}$ & .10 & .04 & $.29^{* *}$ & $.25^{* *}$ \\
\hline $\begin{array}{l}\text { 5. Nepovoljna } \\
\text { sredina }\end{array}$ & & & & & 1 & .02 & -.02 & .12 & .07 & .07 \\
\hline $\begin{array}{l}\text { 6. Konzumacija } \\
\text { droga }\end{array}$ & & & & & & 1 & $.16^{*}$ & $.29^{* *}$ & $.31^{* *}$ & $.69^{* *}$ \\
\hline $\begin{array}{l}\text { 7. Konzumacija } \\
\text { alkoholnih pića }\end{array}$ & & & & & & & 1 & .14 & $.20^{* *}$ & $.59^{* *}$ \\
\hline $\begin{array}{l}\text { 8. Konzumacija } \\
\text { opijata i sedativa }\end{array}$ & & & & & & & & 1 & $.15^{*}$ & $.62^{* *}$ \\
\hline $\begin{array}{l}\text { 9. Konzumacija } \\
\text { cigareta i kanabisa }\end{array}$ & & & & & & & & & 1 & $.65^{* *}$ \\
\hline $\begin{array}{l}\text { 10. Ukupna } \\
\text { konzumacija }\end{array}$ & & & & & & & & & & 1 \\
\hline
\end{tabular}

\section{Predviđanje konzumacije supstanci i interakcije prediktora}

U našem istraživanju zabeležene su značajne korelacije većine faktora konzumacije supstanci sa crtama ličnosti, ali su korelacije spomenutih faktora sa sredinom izostale. Mđutim, neophodno je ispitati i veze između mračnih crta, sredine i konzumacije supstanci u multivarijacionom dizajnu. Stoga, kako bismo utvrdili 
značajne prediktore faktora konzumacije supstanci, koristili smo regresionu analizu (multipla linearna regresija). Svaki od faktora predviđali smo linearnom kombinacijom sledećih prediktora: pol (muškarci su kodirani sa o a žene sa 1), uzrast, obrazovanje, makijavelizam, narcizam, psihopatija, sadizam i sredina. Dodatno, s obzirom na to da su ustanovljene korelacije između faktora konzumacije supstanci, uključena je i mera ukupne konzumacije tj. predviđan je na osnovu iste linearne kombinacije prediktora. U Tabeli 3 prikazano je na kojin način kombinacija navedenih prediktora doprinosi predviđanju svakog od faktora. Odabrana kombinacija prediktora objašnjava najveći procenat varijanse u predviđanju Konzumacije cigareta i kanabisa (20\%). Kod svih regresionih modela ustanovljena je statistička značajnost ali objašnjavaju relativno mali procenat varijanse faktora konzumacije. Najbolji prediktor konzumacije PAS-a je svakako psihopatija pošto predviđa pozitivno sva četiri kriterijuma. Narcisoidnost daje samostalni doprinos predikciji konzumacije cigareta i kanabisa kao i ukupnoj konzumaciji. Makijavelizam i sadizam nisu imali samostalne doprinose predikciji ni jednog kreterijuma; isto se može reći i za nepovoljnu sredinu u detinjstvu. Nije pronađena ni jedna značajna interakcija između mračnih crta i nepovoljne sredine kada je u pitanju predikcija konzumacije supstanci.

Tabela 3: Mračne crte i nepovoljna sredina kao prediktori konzumacije supstanci

\begin{tabular}{|c|c|c|c|c|c|c|c|c|c|c|}
\hline & \multicolumn{2}{|c|}{$\begin{array}{c}\text { Konzumacija } \\
\text { droga }\end{array}$} & \multicolumn{2}{|c|}{$\begin{array}{c}\text { Konzumacija } \\
\text { alkoholnih } \\
\text { pića }\end{array}$} & \multicolumn{2}{|c|}{$\begin{array}{c}\text { Konzumacija } \\
\text { opijata i } \\
\text { sedativa }\end{array}$} & \multicolumn{2}{|c|}{$\begin{array}{c}\text { Konzumacija } \\
\text { cigareta i } \\
\text { kanabisa } \\
\end{array}$} & \multicolumn{2}{|c|}{$\begin{array}{c}\text { Ukupna } \\
\text { konzumacija }\end{array}$} \\
\hline & $\beta$ & $\mathrm{SE}$ & $\beta$ & SE & $\beta$ & SE & $\beta$ & $\mathrm{SE}$ & $\beta$ & $\mathrm{SE}$ \\
\hline Pol & -0.07 & .14 & 0.05 & .15 & -0.27 & .14 & -0.10 & .14 & $-0.15^{* * *}$ & .09 \\
\hline Uzrast & -0.08 & .01 & $-0.22^{* *}$ & .01 & $0.24^{* *}$ & .01 & 0.04 & .01 & -0.01 & .01 \\
\hline Obrazovanje & -0.02 & .10 & 0.13 & .10 & 0.05 & .10 & $-0.14^{* *}$ & .10 & 0.01 & .06 \\
\hline Makijavelizam & -0.14 & .01 & 0.05 & .01 & -0.05 & .01 & -0.03 & .01 & -0.06 & .01 \\
\hline Narcizam & 0.04 & .01 & 0.12 & .01 & -0.01 & .01 & $0.21^{* *}$ & .01 & $0.14^{*}$ & .01 \\
\hline Psihopatija & $0.25^{* *}$ & .02 & $0.19^{* *}$ & .01 & 0.14 & .02 & $0.23^{* * *}$ & .02 & $0.31^{* *}$ & .01 \\
\hline Sadizam & 0.08 & .02 & -0.07 & .02 & 0.12 & .02 & 0.16 & .02 & 0.11 & .01 \\
\hline sredina & -0.03 & .09 & 0.04 & .09 & 0.08 & .09 & 0.03 & .09 & 0.05 & .06 \\
\hline $\mathrm{F}$ & $2.21^{*}$ & & $3.27^{* *}$ & & $4.09^{* *}$ & & $5.80^{* *}$ & & $4.62^{* * *}$ & \\
\hline $\mathrm{R}^{2}$ & .09 & 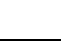 & .12 & & .15 & & .20 & & .166 & \\
\hline
\end{tabular}




\author{
Zbornik IKSI, 1/2021 - A. Damjanović, J. Međedović \\ „Mračna Tetrada i nepovoljni sredinski uslovi kao facilitatori konzumacije \\ psihoaktivnih supstanci”, (str. 69-84)
}

\title{
DISKUSIJA
}

Sprovedenim istraživanjem nastojala se ispitati veza između dimenzija mračne tetrade ličnosti, sredinskih varijabli i konzumacije psihoaktivnih supstanci. Konzumacija psihoaktivnih supstanci, koja ima jasne negativne uticaje na pojedinca, društvo i ekonomiju u užem i širem smislu, se najbolje može razumeti ako se u analizu uključe individualne karakteristike pojedinca, ali i sredinski faktori, što se ovim istraživanjem nastojalo postići. Naša očekivanja su delimično potvrđena - ona koja se odnose na veze između mračnih crta i upotrebe supstanci; ovo se pre svega odnosi na psihopatiju koja je najbolji prediktor svih oblika konzumacije supstanci osobe koje su visoke na ovoj crti imaju povišenu skolnost ka konzumiranju supstanci. Međutim, nije dobijena očekivana povezanost između nepovoljne sredine i konzumacije. Takođe, nisu pronađene značajne interakcije između mračnih crta i nepovoljnog okruženja.

\section{Mračna Tetrada i konzumacija supstanci}

Rezultati dobijeni ovim istraživanjem su u skladu sa prethodnim nalazima u kojima se pokazalo da su mračne crte pozitivno povezane sa konzumacijom psihoaktivnih supstanci, a gde možda i najveći doprinos objašnjenju konzumacije pripada psihopatiji. Ti nalazi pokazuju da je psihopatija pozitivno povezana sa impulsivnošću, jednim od glavnih faktora rizika koji mogu dovesti do konzumiranja psihoaktivnih supstanci (Jones \& Paulhus, 2011), te da psihopate imaju smanjenu sposobnost inhibicije antisocijalnih impulsa (Foster \& Trimm, 2008) i na subkliničkom nivou, životna putanja psihopata može biti samodestruktivna, uključujući i konzumaciju psihoaktivnih supstanci (Fite, Raine, Stouthamer-Loeber, Loeber,\& Pardini, 2010). Mnoga ranija istraživanja su pokazala povezanost između konzumacije psihoaktivnih supstanci i psihopatije, pri čemu se impulsivne karakterisitke psihopatije pokazuju kao najvažnije za objašnjenje konzumacije supstanci (Jones \& Paulhus, 2011; Schulz, Murphy, \& Verona, 2016 ). Veza između zavisnosti od psihoaktivnih supstanci i impulsivnog i neodgovornog ponašanja je najviše bila dosledna kada su u pitanju alkohol, kanabis, kokain i opijati (Walsh, Allen, \& Kosson, 2007) međutim pronađene sui veze sa upotrebom kokaina i zloupotrebom benzodiazepine (Potik, Abramsohn, Schreiber, Adelson, \& Peles, 2019). Postojeći nalazi ukazuju da je psihopatija ne samo dosledno povezana sa upotrebom psihoaktivnih supstanci već i sa uticajem na druge da koriste supstance (Curtis, Richards, \& Jones, 2020) što uvećava destruktivni potencijal psihopatije u socijalnom smislu. Da sumiramo, nalaz dobijen u ovom istraživanju da je psihopatija ključni prediktor konzumiranja supstanci kada su u pitanju crte Mračne Tetrade je kongruentan sa dosadašnjom literaturom o upotrebi PAS-a kod osoba sa povišenim psihopatskim crtama.

Istraživanja su pokazala da se u jednoj grupi alkoholičara ističu antisocijalne i narcističke crte, pripadnici te grupe su bili eksploatišući, prkosni i vrlo neprijateljski 


\section{Zbormik IKSI, 1/2021 - A. Damjanović, J. Međedović „Mračna Tetrada i nepovoljni sredinski uslovi kao facilitatori konzumacije psihoaktivnih supstanci”, (str. 69-84)}

nastrojeni, sa precenjenom slikom o sebi i osećajem da imaju sva prava, a sa nedostatkom osetljivosti ili ravnodušnošću za prava drugih (Corbisiero, \& Reznikoff, 1991). Podaci koje smo mi dobili prema kojima je konzumiranje cigareta i kanabisa povezano sa narcističkim crtama saglasan je sa prethodnim istraživanjima. Postojeći podaci ukazuju da je zajedničko javljanje upotrebe kanabisa i zavisnosti od nikotina povezano sa većom prevalencom narcističkog poremećaja ličnosti (Peters, Schwartz, Wangc, O'Grady, \& Blancoc, 2014), kao i da je narcistički poremećaj ličnosti dobar prediktor (zlo)upotrebe kanabisa (Peters et al., 2014, prema Gillespie et al., 2018).

Kada je reč o sadizmu, agresivnost je jedna od osnovnih osobina, ali i faktor rizika koji mogu dovesti do konzumiranja psihoaktivnih supstanci (Anderson, 2006), a to su i drugi nalazi potvrdili, gde se pokazalo da je agresivnost prediktor konzumacije supstanci u odraslom dobu (Fite et al., 2010). S obzirom da je agesivnost (proaktivna) jedna od ključnih karakterisitka sadizma (Chester, DeWall, \& Enjaian, 2019), očekivali smo slične povezanosti konzumacije i same crte sadizma. U našem istraživanju je dobijeno da sadizam zaista pozitivno korelira sa određenim tipovima konzumacije PAS-a, međutim on nema samostalni doprinos predikciji, pa se njegova asocijacija sa konzumacijom najverovatnije može pripisati vezama sa psihopatijom. Naime negativni, afektivitet, antagonizam i agresivno ponašanje su pored sadizma pouzdani korelati i psihopatske ličnosti (Walsh, Allen, \& Kosson, 2007) i izgleda da oni kroz psihopatiju, a ne kroz sadizam ostvaruju vezu sa konzumacijom supstanci.

Makijavelističko ponašanje je relativno drugačije od ostalih crta, te osobe ograničavaju svoju agresivnost u situacijama gde takvo ponašanje može dovesti do dugoročnih ciljeva, što omogućuje barem neku suzdržanost od kontraproduktivnih ponašanja (Jones \& Paulhus, 2010). Ovaj nalaz je u skladu sa našim rezultatima koji nisu pokazali prediktivne moći makijavelizma kada je u pitanju konzumacija. Ipak, makijavelizam može imati i negativne obrasce ponašanja u zavisnosti od pola (Szabó \& Jones, 2019), što dalje može upućivati na njegov doprinos konzumaciji psihoaktivnih supstanci. Ovo istraživanje nije imalo dovoljnu snagu (usled male veličine uzorka) da testira interakcije između mračnih crta i pola ali u budućim studijama uloga pola kao moderatora povezanosti između mračnih crta i konzumacije bi trebalo da bude istražena.

\section{Nepovoljna sredina tokom odrastanja i konzumacija supstanci}

Hipoteza po kojoj bi nepovoljno sredinsko okruženje bilo pozitivno povezano sa frekventnošću konzumiranja psihoaktivnih supstanci, nije naišla na potvrdu $u$ sprovedenom istraživanju. U dosadašnjim istraživanjima je prisutna debata o tome da li konzumacija psihoaktivnih susptanci uzrok nepovoljnog sredinskog okruženja, između ostalog i siromaštva ili je posledica istog (Johnson \& Chamberlain, 2008). Kako se povećava potreba za konzumacijom psihoaktivnih supstanci, određene finansijske rezerve se isrcpljuju kako bi se zadržala ova skupa „navika“, tako da ljudi mogu sebe dovesti do velikih finansijskih gubitaka, pa i iseljenja (Bessant et al., 2002) ili do velikih porodičnih rasprava, svađa i razvoda (Coumans \& Spreen, 2003). Suprotno ovom modelu, druga istraživanja govore o tome da se ljudi u 


\section{Zbormik IKSI, 1/2021 - A. Damjanović, J. Međedović \\ „Mračna Tetrada i nepovoljni sredinski uslovi kao facilitatori konzumacije psihoaktivnih supstanci", (str. 69-84)}

siromaštvu susreću sa okruženjem u kom je konzumacija supstanci nešto što je potpuno socijalno prihvatljivo i što može biti faktor rizika za konzumaciju istih (Auerswald \& Eyre, 2002). Ovu debatu čini komplikovanom činjenica da su nepovoljni sredinski faktori ili konzumacija psihoaktivnih supstanci retko izazvani jednim izolovanim faktorom koji deluje nezavisno (Johnson \& Chamberlain, 2008) i da postoje znatne varijacije između pojedinačnih slučajeva,što može biti jedno od objašnjenja da u ovoj studiji nije pronađena veza između sredine i konzumacije supstanci. Međutim, možemo istaći i određene metodološke aspekte studije koji su mogli umanjiti verovatnoću detekcije značajnog efekta, odnosno način na koji je mereno nepovoljno sredinsko okruženje: reč je o retroaktivnom merenju sredinskih uslova iz detinjstva. Naši ispitanici su morali dati odgovore na pitanja iz njihove davne prošlosti, usled čega ne možemo sa sigurnošću tvrditi da su njihova sećanja sačuvana i u skladu sa realnim činjenicama o tom periodu detinjstva.

\section{OGRANIČENJA I PREPORUKE ZA BUDUĆA ISTRAŽIVANJA}

Ovo istraživanje ima nekoliko ograničenja. Glavno ograničenje je veličina uzorka: mala veličina uzorka je smanjila snagu studije i povećala verovatnoću greške tipa 1 - da u populaciji postoje značajni efekti ali mi nismo uspeli da ih detektujemo. Ako se pogledaju visine korelacija i $\beta$ koeficijenata $u$ regresionim analizama jasno je da bi neki od ovih koeficijenata bili značajni kada bi bili testirani na nešto većem uzorku. Dalje, za uzorkovanje je korišćena metoda snežne gudve što je moglo dovesti do homogenosti u socioekonomskom statusu, kao i smanjenoj varijansi ispitivanih varijabli. Takođe, korišćen je uzak starosni raspon (20-34 godine), što znači da je istraživanje obuhvatilo mlade odrasle ispitanike i da i u pogledu uzrasta ispitanika postoji određena homogenost. Retroaktivni pristup zadavanja upitnika o nepovoljnom okruženju, mogao je dovesti do nepozdanosti tih istih rezultata. Trebalo bi koristiti širi spektar metodoloških pristupa, kao što su npr. podaci od ispitanicima bliskih osoba. Na upitniku koji ispituje upotrebu PAS, bilo bi dobro da su neke klase supstanci preciznije predstavljene, kao što su npr.opijati/analgetici. Na kraju, i neke od mračnih crta imaju svoje subdimenzije (što se posebno odnosi na psihopatiju) tako da bi buduća istraživala imala benefit i od multidimenzionalnih mera Mračne Tetrade.

\section{ZAKLJUČAK}

Upotreba supstanci u opštoj populaciji ubrzano postaje sve veći problem javnog zdravlja i povezana je sa visokim cenama na socijalnom, psihološkom i planu fizičkog zdravlja, sem toga, pogađa i korisnike PASa i osobe povezane sa korisnikom (Ham \& Hope, 2003). Dodatno komplikuje situaciju i problem zavisnosti od više supstanci istovremeno (Martins, Ghandour,\& Chilcoat, 2007). Takođe, opijati i sedativi su lako dostupni, nažalost i bez recepta, a sem toga, prihvatljiviji su u odnosu na druge PAS, a adolescenti smatraju da su ove droge bezbednije od nedozvoljenih droga (Fleary, Heffer, Lisako, \& McKyer, 2013). Sve navedeno vodi 


\author{
Zbormik IKSI, 1/2021 - A. Damjanović, J. Međedović \\ „Mračna Tetrada i nepovoljni sredinski uslovi kao facilitatori konzumacije \\ psihoaktivnih supstanci”, (str. 69-84)
}

zaključku da bi trebalo posvetiti pažnju prediktorima upotrebe psihoaktivnih supstanci, u cilju smanjenja (zlo)upotrebe PAS kod osoba koje poseduju rizikofaktore kada je u pitanju upotreba PAS-a bilo da su oni ličnosne ili sredinskokontekstualne prirode. Naše je mišljenje da upravo interakcionistički pristup, koji obuhvata i dispozicionalne konstrukte i sredinske faktore, ima najveću eksplanatornu moć kada je u pitanju predikcija upotrebe supstanci a samim tim i intervencija u cilju prevencije upotrebe supstanci ili menjanja ovakvog ponašanja ukoliko je ono već razvijeno.

\title{
LITERATURA
}

(1) Anderson, P.(2006). Global use of alcohol, drugs and tobacco. Drug Alcohol Revew, 25,489-502. doi: https://doi.org/10.1080/09595230600944446

(2) Alsheikh Ali, A. S. (2020). Delinquency as predicted by dark triad factors and demographic variables. International Journal of Adolescence and Youth, 25, 661675. doi:https://doi.org/10.1080/02673843.2020.1711784

(3) Auerswald, C., \& Eyre, S. (2002). Youth homelessness in San Francisco: A life cycle approach. Social Science and Medicine, 54, 1497-1512. doi:https://doi.org/10.1016/So277-9536(01)00128-9

(4) Bessant, J., Coupland, H., Dalton, T., Maher, L., Rowe, J., \& Watts, R. (2002). Heroin users, housing and social participation: Attacking social exclusion through better housing. Melbourne: Australian Housing and Urban Research Institute.

(5) Buckels, E.E., Jones, N.D., \& Paulhus, L.D. ( 2013 ). Behavioral Confirmation of Everyday Sadism. . Association for psychological sience, 2O, 1-9. doi:https://doi.org/10.1177/0956797613490749

(6) Casillas, A., \& Clark, L. A. (2002). Dependency, impulsivity and self-harm: Traits hypothesized to underlie the association between cluster B personality and substance use disorders. Journal of personality disorders, 16, 424-436. doi: https://doi.org/10.1521/pedi.16.5.424.22124

(7) Chester, D. S., DeWall, C. N., \& Enjaian, B. (2019). Sadism and aggressive behavior: Inflicting pain to feel pleasure. Personality and social psychology bulletin, 45(8), 1252-1268. https://doi.org/10.1177\%2Fo146167218816327

(8) Christie, R. \& Geis, F.L. (1970). Studies in Machiavellianism. London: Academic Press.

(9) Conger, R. D., Wallace, L. E., Sun, Y., Simons, R. L., McLoyd, V. C., \& Brody, G. H. (2002). Economic pressure in African American families: A replication and extension of the family stress model. Developmental Psychology, 38, 179-193. doi: http://dx.doi.org/10.1037/oo12-1649.38.2.179

(10) Corbisiero, J. R., \&Reznikoff, M. (1991).The relationship between personality type and style of Alcohol Use. Journal of Clinical Psychology, 47, 291-298. doi: https://doi.org/10.1002/1097-4679(199103)47:2<291::AIDJCLP2270470217>3.0.CO;2-S

(11) Coumans, M., \& Spreen, M. (2003). Drug use and the role of homeless in the process of marginalization. Substance Use \& Misuse, 38, 311-338. doi: https://doi.org/10.1081/JA-120017376

(12) Curtis,R.S.,Richards,D.K.,\& Jones,N.D. (2020): The Association between Psychopathy and Influencing Others to Use Substances, Substance Use \& Misuse, 7 , 1097-1105. doi: https://doi.org/10.1080/10826084.2020.1729196 


\section{Zbormik IKSI, 1/2021 - A. Damjanović, J. Međedović „Mračna Tetrada i nepovoljni sredinski uslovi kao facilitatori konzumacije psihoaktivnih supstanci", (str. 69-84)}

(13) Dinić, B. M., Petrović, B., \& Jonason, P. K. (2018). Serbian adaptations of the Dark Triad Dirty Dozen (DTDD) and Short Dark Triad (SD3). Personality and Individual Differences, 134, 321-328. doi: https://doi.org/10.1016/j.paid.2018.06.018

(14) Dragioti, E., Damigos, D., Mavreas, V., \&Gouva, M. (2012). Effects of childhood trauma on hostility, family environment and narcissism of adult individuals. International Journal of Caring Sciences, 5, 137-146.

(15) Dube,S.R., Felitti,V.J., Dong,M., Chapman,D.P., Giles,W.H., \& Anda,R.F. (2012). Childhood abuse, neglect, and household dysfunction and the risk of illicit drug use: The Adverse Childhood Experiences Study. Pediatrics,111, 564-572. doi: https://doi.org/10.1542/peds.111.3.564

(16) Fite, P. J., Raine, A., Stouthamer-Loeber, M., Loeber, R., \& Pardini, D. A. (2010). Reactive and proactive aggression in adolescent males: Examining differential outcomes 10 years later in early adulthood. Criminal Justice and Behavior, 37, 141-157. doi: https://doi.org/10.1177/0093854809353051

(17) Fleary, S. A., Heffer, R. W., \&McKyer, E. L. J. (2013).Understanding Nonprescription and Prescription Drug Misuse in Late Adolescence/Young Adulthood. Journal of Addiction, 2013, 1-8. doi:https://doi.org/10.1155/2013/709207

(18) Foster, J. D. i Trimm, R. F. (2008). On being eager and uninhibited: Narcissism and approach-avoidance motivation. Personality and Social Psychology Bulletin, 34, 10041017. doi: https://doi.org/10.1177/0146167208316688

(19) Foulkes, L. (2019). Sadism: Review of an elusive construct. Personality and Individual Differences, 151. doi: https://doi.org/10.1016/j.paid.2019.07.010

(20) Gillespie, N. A., Aggen, S. H., Neale, M. C., Knudsen, G. P., Krueger, R. F., South, S. C., ... Reichborn-Kjennerud, T. (2018). Associations between personality disorders and cannabis use and cannabis use disorder: a population-based twin study. Addiction, 113, 1488-1498. doi: https://doi.org/10.1111/add.14209

(21) Ham, L. S., \& Hope, D. A. (2003). College students and problematic drinking: A review of the literature. Clinical psychology review, 23, 719-759. doi: https://doi.org/10.1016/So272-7358(03)00071-o

(22) Hare, R. D. (2003). The Hare Psychopathy Checklist-Revised (2nd ed.). Toronto: Multi-Health Systems.

(23) Hicks,B.M.,Vaidyanathan,U., \&Patrick,J.C.(2010). Validating Female Psychopathy Subtypes: Differences in Personality, Antisocial and Violent Behavior, Substance Abuse, Trauma and Mental Health. Personality Disorders: Theory, Research, and Treatment, 1, 38-57. doi: https://doi.org/10.1037/aoo18135

(24) James, L. M., \& Taylor, J. (2007). Impulsivity and negative emotionality associated with substance use problems and Cluster B personality in college students. Addictive Behaviors, 32, 714-727. doi: https://doi.org/10.1016/j.addbeh.2006.06.012

(25) Johnson, G.,\& Chamberlain, C. (2008). Homelessness and substance abuse: which comes first?. Australian Social Work, 4, 342-356. doi: https://doi.org/10.1080/03124070802428191

(26) Jonason,P.K.,Li,N.P.,Webster,D.G., \&Schmitt,D.P.(2009). The Dark Triad: Facilitating a short-term mating strategy in men. European Journal of Personality, 23, 5-18. https://doi.org/10.1002\%2Fper.698

(27) Jones, D. N. i Paulhus, D. L. (2010). Different provocations provoke aggression in psychopaths and narcissists. Social Psychological and Personality Science, 1, 12-18. doi: https://doi.org/10.1177/1948550609347591 


\author{
Zbormik IKSI, 1/2O21 - A. Damjanović, J. Međedović \\ „Mračna Tetrada i nepovoljni sredinski uslovi kao facilitatori konzumacije \\ psihoaktivnih supstanci”, (str. 69-84)
}

(28) Jones, D. N., \& Paulhus, D. L. (2011). The role of impulsivity in the Dark Triad of personality. Personality and Individual Differences, 51, 679-682. doi: https://doi.org/10.1016/j.paid.2011.04.011

(29) Kotov, R., Gamez, W., Schmidt, F., \& Watson, D. (2010). Linking big personality traits to anxiety, depressive, and substance use disorders: A meta-analysis. Psychological Bulletin, 136, 768-821. doi: https://doi.org/10.1037/ao020327

(30) Kovačević, M.(2002). Zavisnosti od supstanci-etiologija. Engrami,24, 3-4.

(31) Marković,A.(2016). Istraživanja s alkoholom povezanih poremećaja i problema u Republici Hrvatskoj. Edukacijsko-rehabilitacijski fakultet, Zagreb. doi: https://urn.nsk.hr/urn:nbn:hr:158:117735

(32) Martins, S. S., Ghandour, L. A., \& Chilcoat, H. D. (2007).Pathways between ecstasy initiation and other drug use. Addictive Behaviors, 32, 1511-1518. doi: https://doi.org/10.1016/j.addbeh.2006.11.003

(33) Međedović, J. (2017). Aberrations in emotional processing of violence-dependent stimuli are the core features of sadism. Motivation and Emotion, 41, 273-283. doi: https://doi.org/10.1007/s11031-016-9596-o

(34) Međedović, J. (2019). Life history in a postconflict society. Human nature, 30(1), 59-70. https://doi.org/10.1007/s12110-018-09336-y

(35) Međedović, J. (2020). Examining the link between religiousness and fitness in a behavioural ecological framework. Journal of biosocial science, 52, 756-767. doi: https://doi.org/10.1017/So021932019000774

(36) Međedović, J., \& Knežević, G. (2019). Dark and peculiar. Journal of Individual Differences, 4O, 92-103. doi: https://doi.org/10.1027/1614-0001/a000280

(37) Međedović, J., \& Kovačević, U. (2020). Sadism as a key dark trait in the link between football fandom and criminal attitudes. Journal of Individual Differences, 42, 9-18. doi: https://doi.org/10.1027/1614-0001/aooo325

(38) Međedović, J., \& Petrović, B. (2015). The dark tetrad - Structural properties and location in the personality space. Journal of Individual Differences, 36, 228-236. doi: https://doi.org/10.1027/1614-0001/aooo179

(39) Mitrović, S. (2005). Poraz adolescencije - droge i zavisnost. Psihijat.dan., 37,109-118.

(40) Neumann, C. S. i Hare, R. D. (2008). Psychopathic traits in a large community sample: Links to violence, alcohol use, and intelligence. Journal of Consulting and Clinical Psychology, 76, 893-899. doi: https://doi.org/10.1037/0022-006X.76.5.893

(41) Pajević, M., Gvozden, T.V., Stevanović, N., Neumann, C.S. (2018). The Relationship between the Dark Tetrad and a two-dimensional view of empathy. Personality and Individual Differences, 123, 125-130. https://doi.org/10.1016/j.paid.2017.11.009

(42) Paulhus, D. L. (2014). Toward a taxonomy of dark personalities. Current Directions in Psychological Science, 23, 421-426. doi: https://doi.org/10.1177/0963721414547737

(43) Paulhus, D.L., \& Jones, D.N. (2015). Measures of dark personalities. In G.J. Boyle, D.H. Saklofske, \& G. Matthews (Eds.), Measures of personality and social psychological constructs (pp. 562-594). London, United Kingdom: Academic Press.

(44) Peters, E. N., Schwartz, R. P., Wang, S., O’Grady, K. E., \& Blanco, C. (2014). Psychiatric, psychosocial, and physical health correlates of co-occurring cannabis use disorders and nicotine dependence. Drug and Alcohol Dependence, 134, 228234. doi: https://doi.org/10.1016/j.drugalcdep.2013.10.003

(45) Potik,D., Abramsohn,Y., Schreiber,S., Adelson,M.,\& Peles,E.(2019). Drug abuse and bihevioral transgressions during methadone maintenance treatment (mmt) are 
Zbornik IKSI, 1/2021 - A. Damjanović, J. Međedović „Mračna Tetrada i nepovoljni sredinski uslovi kao facilitatori konzumacije
psihoaktivnih supstanci”, (str. 69-84)

related to high psychopathy levels. Substance Use \& Misuse, 460-468. doi: https://doi.org/10.1080/10826084.2019.1685546

(46) Quednow, B.B, Hulka, L.M., Preller, K.H., Baumgartner, M.R., Eisenegger, C., \& Vonmoos, M. (2017). Stable self-serving personality traits in recreational and dependent cocaine users. Plos one, 12, e0172853. doi:https://doi.org/10.1371/journal.pone.0172853

(47) Schulz, N., Murphy, B., \& Verona, E. (2016). Gender differences in psychopathy links to drug use. Law and Human Behavior, 40, 159-168. doi: https://doi.org/10.1037/lhboooo165

(48) Szabó, E., \& Jones, D. N. (2019). Gender differences moderate Machiavellianism and impulsivity: Implications for Dark Triad research. Personality and Individual Differences, 141, 160-165. doi: https://doi.org/10.1016/j.paid.2019.01.008

(49) Trull, T. J., Waudby, C. J., \& Sher, K. J. (2004). Alcohol, tobacco, and drug use disorders and personality disorder symptoms. Experimental and clinical psychopharmacology, 12, 65-75. doi: https://doi.org/10.1037/1064-1297.12.1.65

(50) Walsh, Z., Allen, L. C., \& Kosson, D. S. (2007). Beyond social deviance: Substance use disorders and the dimensions of psychopathy. Journal of Personality Disorders, 21, 273-288. doi: https://doi.org/10.1521/pedi.2007.21.3.273

(51) Weng, X. Ran, M.S., Chui, H.W. (2016). Juvenile delinguency in Chinese adolescents: An ecological review of the literature, Aggression and violent behavior, 31, 26-36. https://doi.org/10.1016/j.avb.2016.06.016

(52) Williams, K. M., Paulhus, D. L., \& Hare, R. D. (2007). Capturing the four-factor structure of psychopathy in college students via self-report. Journal of personality assessment, 88, 205-219. doi: https://doi.org/10.1080/00223890701268074 


\section{DARK TETRAD AND THE DYSFUNCTIONAL FAMILY ENVIRONMENT AS FACILITATORS OF THE CONSUMPTION OF PSYCHOACTIVE SUBSTANCES}

The Dark Tetrad is a psychological concept that originally consisted of three empirically overlapping components, Machiavellianism, narcissism and psychopathy; finally, sadism is included in the description of dark traits as well. The aim of this study was to examine the relationship between the Dark Tetrad traits, unfavorable environmental environment during the childhood, and consumption of psychoactive substances (CPS). The data were collected via an online survey and the analyses were conducted on a sample of 239 respondents (55.65\% of female respondents). The results showed that psychopathy is the most important predictor of CPS because it independently and positively predicted all examined types of psychoactive substances' consumption. Narcissism has shown an independent positive contribution in the prediction of cigarettes and cannabis consumption, as well as the overall measure of substance use. Machiavellianism and sadism had positive correlations with some of the examined criteria, but not an independent contribution in the regression models; this means that the detected bivariate associations can be reduced to the relations between other dark traits and consumption of CPS, most likely psychopathy. No connections were found between the unfavorable environment and the criterion variables, neither the interactions between dark traits and the environment in the prediction of CPS. We discuss the implications of the findings, taking into account the limitations of the research itself.

KEY WORDS: Dark Tetrad / psychoactive substances consumption / dysfunctional family environment 